\title{
Integrative Versus Delay Line Characteristics of Cerebellar Cortex
}

\author{
W. A. MacKAY AND J. T. MURPHY
}

SUMMARY: In order to determine which of two general models ("tapped delay line" or "integrator") provides a more accurate description of mammalian Purkinje cell (P-cell) activation by natural stimulation, the spatial and temporal characteristics of a population of neurons in cerebellar cortex responsive to small controlled stretches of forelimb muscles were examined in awake, locally anesthetized cats. Stretch of a single wrist muscle excited P-cells over a distance of about $1 \mathrm{~mm}$ in the long axis of a folium, a span which is at most half the length of parallel fibers. Both granule cells and molecular layer interneurons were excited over a wider zone than P-cells.

Furthermore, P-cells across a response zone all fired on the average at the same time, as determined by computing peristimulus cross-interval histog-

RÉSUMÉ: Pour déterminer lequel des deux modeles genéraux ("tapped delay line" ou "integrator") donne une déscription plus précise des réponses des cellules de Purkinje (C.P.) à la stimulation naturelle, les caractéristiques spatiales et temporelles d'une population de neurones dans le cortex cérébelleax, activée par le tirage des mascles de la patte antéricure, étaient examinées dans les chats éveillés. Le tirage d'un muscle du poignet a activé des C.P. sur une distance à peu près d'un $\mathrm{mm}$ dans l'axe longitudinale d'une feuille, d'une longeur égale au plus la moitié de la longeur des fibres parallèles. Les cellules des grains et les interneurones de la couche moléculaire étaient excitées dans une région plus extensive que les C.P.

D'ailleurs, C.P. à travers une zone de réponse ont toutes déchargées en moyenne au même instant, ce qui était déterminé par le calcul des histo-

From the Department of Physiology, University of Toronto, Toronto, Canada.

Reprint requests to Prof. John T. Murphy, Department of Physiology, Medical Sciences Building. University of Toronto, Toronto, Ont. M5S 1A8, Canada. rams from pairs of simultaneously recorded neurons. Consistent delays could only be demonstrated in the minimal response latencies as measured from peristimulus time histograms. These delays, however, were longer than could be ascribed to parallel fiber conduction velocity.

No evidence, therefore, was found in cat cerebellum to support the "tapped delay line" model, which postulates the successive activation of P-cells as an excitatory volley travels along a parallel fiber beam. Instead, an integrative mode of operation seems to predominate: a relatively wide substratum of activated granule cells simultaneously activates a narrower focus of $P$-cells centrally situated with respect to the granule cell population. The role of inhibitory interneurons in promoting the "integrator" model is discussed.

grammes d'intervalles croisés des paires de neurones simultanément enregistrées. Un délai constant ne se revélait que dans les latences minimes mésurés dans des histogrammes peristimulus. Cependant, ces délais étaient plus longues que ceux atribuable au velocité de conduction des fibres parallèles.

Dans le cervelet félin, donc, on ne trouvait aucune évidence supportant le modele "lapped delay line" qui suppose une activation successive des C.P. le long d'un rayon de fibres parallèles. Au contraire, le cortex semble fonctionner comme "integrator": une collche assez large de cellules des grains excite simultanément un foyer plus étroit de C.P. situé au-dessus le centre de la population activé de cellules des grains. On discute le rôle des interneurones inhibitrices en facilitant le modèle intégratif.

\section{INTRODUCTION}

The orderly distribution of parallel fibers through the orthogonallyoriented dendritic trees of Purkinje cells (P-cells) has inspired two general schools of thought concerning the operation of cerebellar cortex. Braitenberg (1961) and later Freeman (1969) have suggested that the parallel fibers constitute a delay line, "tapped" at regular intervals by $\mathrm{P}$-cell dendritic arborizations (Fig. 1). In support of this hypothesis Freeman and Nicholson (1970) have demonstrated the presence of fixed delays between discharges of frog P-cells, in response to natural vestibular stimulation, totally attributable to the conduction time of the parallel fiber beam linking the cells. Kornhuber (1971) has also adopted the delay line model as a basic component in his concept of cerebellar cortical function, namely the preprogramming of fast movement duration.

On the other hand, Fox and Barnard (1957) have stressed that the cerebellar cortex is an ideal structure for maximum divergence of inputs to many $P$-cells and at the same time maximum convergence of inputs onto single P-cells. Similarly, extensive studies of mammalian $P$-cell responses to various afferent systems (Allen et al., 1974; Eccles et al., 197 Ic, 1972; Freeman, 1970; Murphy et al., 1973) have consistently revealed a convergence of different inputs onto single cells. While not refuting the delay line model, the prominence of P-cell "integration" (Eccles et al., 1971c, 1972) suggests that parallel fibers may have a function entirely different from timing. Thus, parallel fibers originating from either side of a P-cell dendritic tree might convey excitatory inputs to it 
frontal view

TAPPED DELAY LINE

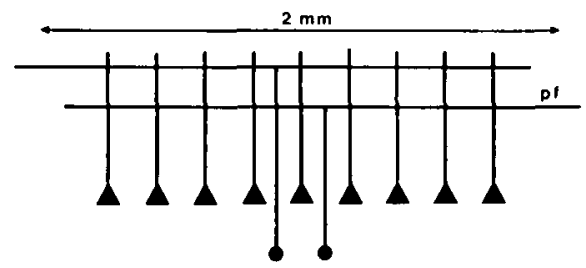

horizontal view $2 \mathrm{~mm}$

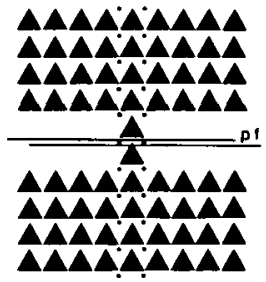

INTEGRATOR

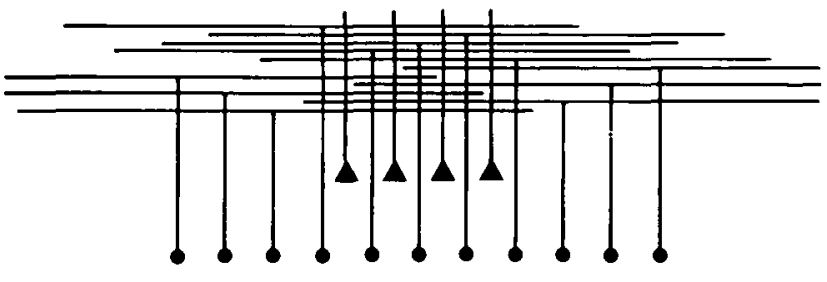

A Purkinje cell

granule cell cluster

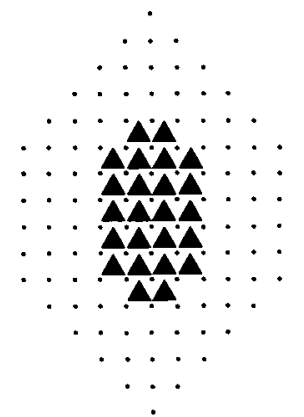

Figure 1-Schematic diagrams illustrating two general lumped models of cerebellar operation. Only the P-cell populations successfully fired by the indicated groups of parallel fibers (pf) are outlined. Some of the P-cells are omitted from the upper horizontal view of unfolded cortex to show the parallel fiber orientation. An average pf length of $2 \mathrm{~mm}$ is assumed in this and subsequent figures.

from a wide substratum of granule cells, mediating signals from a great variety of afferent sources. This viewpoint of parallel fiber function is labelled the "integrator" model in figure 1 .

The major difference between the two models schematically represented in figure 1 is the $P$-cell threshold to parallel fiber input which each implies. For the delay line model this threshold must be relatively low, so that a long string of P-cells may be excited by a "beam" of parallel fibers emanating from a restricted locus of active granule cells. If however, a high density of simultaneously active parallel fibers (arising from a relatively large number of granule cells) is required to excite a P-cell to fire, it is unlikely that the delay line configuration could supply enough excitatory activity to raise the P-cells to threshold in mammalian cerebella. The "integrator" configuration would then predominate.

This study was undertaken to determine which of these two general models best described the temporal and spatial response pattern of feline cerebellar cortex to a discrete proprioceptive stimulus. The relative distribution of responsive cells in all three cortical layers was studied as accurately as possible in the direction of parallel fiber spread. Timing differences between P-cell discharges across a response zone were investigated by measuring' the minimum response latency from peri-stimulus time histograms (PSTH) for each neuron, and by constructing cross-interval histograms (Perkel et al., 1967) from simultaneously recorded pairs of P-cells. It was expected that delays attributable to conduction time along the parallel fibers would be found if the cerebellar cortex performed as a delay line. If, however, the integrator model were operative, it was anticipated that most P-cells would respond either at the same time, or with delays due to synaptic summation not directly predictable from parallel fiber conduction velocity.

Some of our findings have been previously mentioned in abstract form (Mackay and Murphy, 1973, 1975).

\section{METHODS \\ Surgical preparation and muscle stimulation}

Twenty adult cats weighing 2-4 $\mathrm{Kg}$. were used in this study. Under general halothane anesthetic (Fluothane, Ayerst) the right humerus was broken and distal segment solidly fixed to the stimulator frame. The distal tendons of 2 muscles, extensor digitorum communis (EDC) and its antagonist palmaris longus (PL), were dissected out and attached to separate vibrators with non-compliant suture. The nerve supply to these muscles was left intact, but the rest of the right forelimb was denervated.

The right cerebellar cortex was exposed just anterior to the fissura prima (lobule V), and covered with a thin layer of agar which was continuously warmed thereafter by a $37^{\circ} \mathrm{C}$ saline drip. General anesthesia was discontinued after the preparation was complete, about 1 hour prior to recording. All wound margins, pressure points and the sensory divisions of the trigeminal nerve were infiltrated with $2 \%$ lidocaine at regular intervals. The animal was paralyzed with gallamine triethiodide administered through an infusion pump, and positive-pressure ventilation begun.

Regional anesthesia was applied repeatedly to prevent increases in either pupillary mydriasis or arterial blood pressure, which are indicators of incipient discomfort. Other precautions taken to ensure the animal's comfort have been described previously (Murphy et al., 1973).

While recording from neurons, muscle stretches of about $100 \mathrm{msec}$ duration and $10 \mathrm{msec}$ rise time were applied to 1 or 2 muscles at a time, at a rate of about $0.5 \mathrm{~Hz}$. The amplitude of muscle stretch was maintained at a constant value throughout an experiment, varying from preparation to preparation within the range 0.5 to $1.0 \mathrm{~mm}$.

\section{Unit classification}

Extracellular recordings of cerebellar cortical neurons were made using micropipettes filled with $3 \mathrm{M}$ $\mathrm{NaCl}$. The electrodes had a tip 

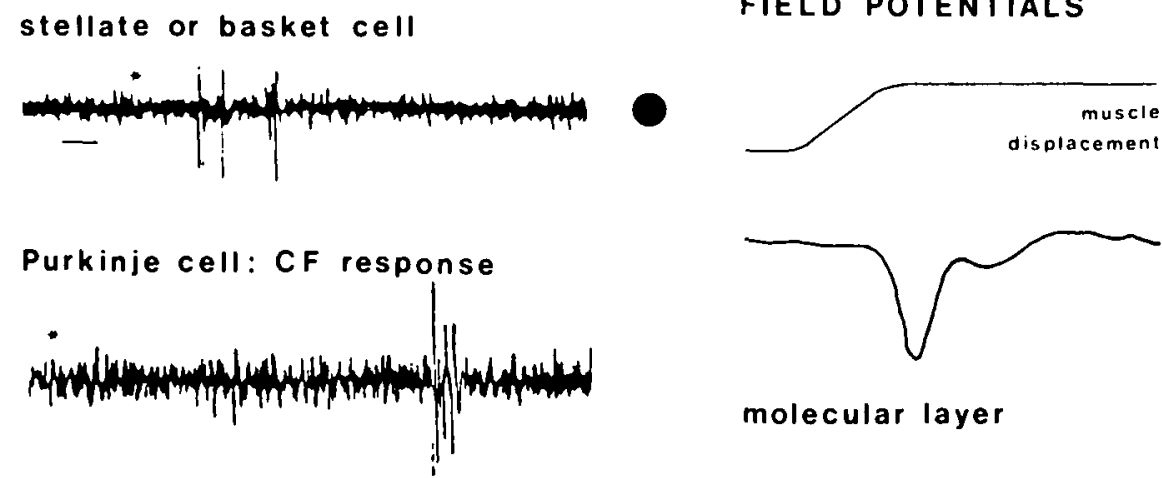

molecular layer

Purkinje \& basket cell

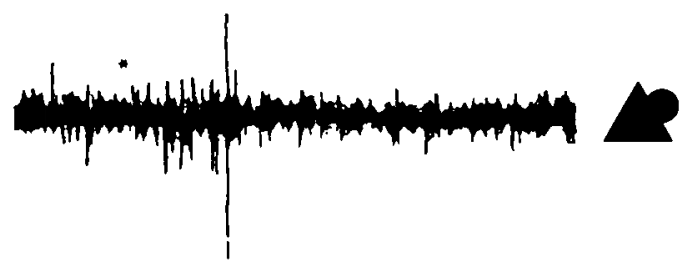

Purkinje cell: MF response
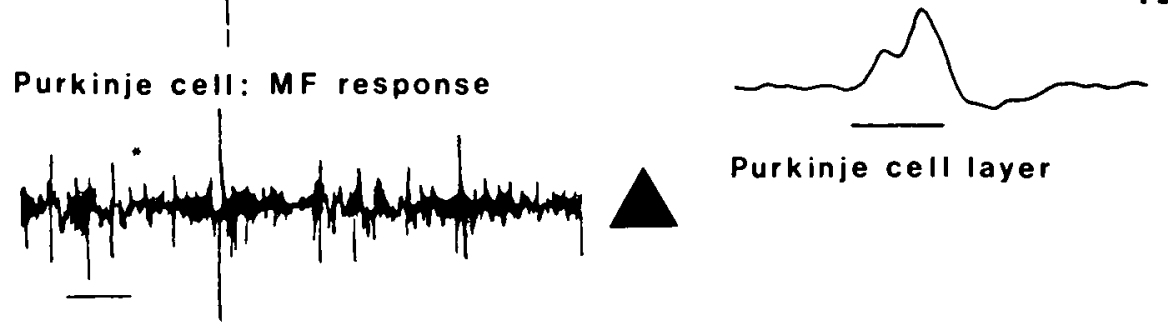

Purkinje cell layer
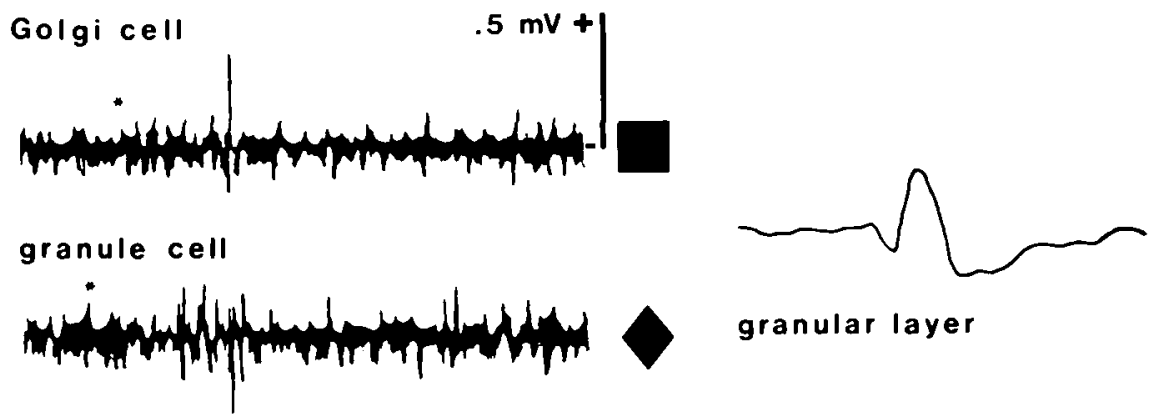

granular layer

Figure 2-The cerebellar key used for identifying single units. Above the single unit records on the left, asterisks indicate the beginning of muscle stretch. Horizontal calibration marks for the upper and lower three traces and for the averaged field potentials are each $10 \mathrm{msec}$. The accompanying symbols are those used in figure 5 .

diameter of $1 \mu$ or less and resistances of 2-8 megohms. The classification of units (Fig. 2) relied on laminar identification; for this purpose evoked field potentials were monitored and averaged at the same time as spike activity. The 3 cortical layers generate distinctive field potentials in response to muscle stretch (Kwan and Murphy, 1974). Large amplitude units which were located in the P-cell layer, exhibited both "simple" and "complex" spikes, and which showed a response to muscle stretch consisting of only 1 or 2 simple spike discharges were considered to be P-cells. If a typical climbing fiber response was not present but the unit was located in the P-cell layer and met the other criteria, it was still classified as a P-cell (cf. Eccles et al., 1971b).

Similar units in the granular layer, but without complex spikes, were classified as Golgi cells (cf. Walsh et al., 1974). Units which responded to muscle stretch with a short burst of spikes, generally of relatively low amplitude, were identified as molecular layer interneurons (stel- late and basket cells) if located in the molecular layer, or as granule cells if located in the granular layer (Fig. 2). All of these units showed an initial negative polarity and were therefore assumed to mainly represent potentials from somata or primary dendrites rather than from passing axons.

From the study of Walsh and coworkers (1974) on the cerebellar cortex of turtles, it would appear that the glomerular terminals of mossy fibers are much more easily recorded from than granule cells. These authors even suggest that granule cell somata do not normally support action potentials. How similar the situation may be in cat cerebellum is not clear, but several points can be made. Potentials recorded from mossy fibers are initially positive (ibid.). The potentials which we identified as originating from granule cells usually showed an initial negative polarity. Moreover, the majority of glomeruli in turtle cerebellum are larger than those in the cat, and have a central mossy fiber terminal which approaches the shape of a medium-sized neuronal cell body (Mugnaini et al., 1974) instead of the highly evaginated and convoluted mammalian rosette (Eccles et al., 1967). Also, mammalian glomeruli are much more fully encapsulated by glial processes than are those in the turtle. Nevertheless, Eccles and colleagues (1971a) have recorded from both mossy fibers and granule cells in cat cerebellum. Therefore, it cannot be excluded that some of the units labelled "granule cells" in this report may in fact have been mossy fiber terminals. But, neurons in the external cuneate nucleus ( $F$. Johnson and $J$. T. Murphy, unpublished observations) and rostral spino-cerebellar tract cells (MacKay and Murphy, 1974) do not fire in a burst in response to muscle stretch, and mossy fibers from lateral reticular nucleus mainly respond much later (ibid.) than the vast majority of burst units recorded here. Hence, most of our granular layer burst units are probably granule cells, and those that were not can nonetheless be assumed to indicate a locus of granule 
cell response. The synaptic linkage from individual mossy fibers to individual granule cells is quite powerful, with little attenuation along granule cell dendrites (Mugnaini et al., 1974).

Recording and analysis of two simultaneous spike trains

As part of the experimental strategy to uncover the exact time relation between responses of P-cells along a "beam" of parallel fibers, simultaneous recordings were made from 2 P-cells separated by varying distances in the long axis of a folium. Two micropipettes were employed. One was positioned in the P-cell layer at what was subjectively judged to be the center of a zone responsive to muscle stretch (region of the largest evoked field potentials). This electrode remained stationary throughout the experiment. The other electrode, angled $45^{\circ}$ with respect to the first, was moved to either side of the first in 200 $\mu$ increments, following the long axis of the folium (Fig. 7). The alignment of the 2 electrodes was performed visually and left a gap, in the experiment illustrated, of 200-400 $\mu$ between the tip of the stationary electrode and the line connecting the tip positions of the moving electrode, as judged from the histological determination of electrode position.

Ideally, the compared P-cells should be excited by a common bundle of parallel fibers. In practice, this qualification is impossible to satisfy because P-cells are neither rectilinearly arranged nor in synaptic contact with all of the parallel fibers passing through their dendritic trees (Palkovits et al., 1971). Local stimulation of parallel fiber bundles would have aided the selection of P-cells excited by a restricted "beam", but was not employed in these experiments because of the extreme vulnerability of mossy fiber-mediated responses of P-cells to even slight cortical damage. Fortunately, the need for strictly aligning the compared P-cells on a shared parallel fiber bundle is alleviated by the profuse branching of mossy fibers in the sagittal plane (Eccles et al., 1967),
A

\section{frame-shifted}

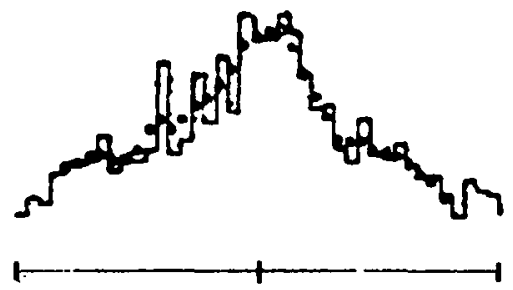

\section{non-shifted}

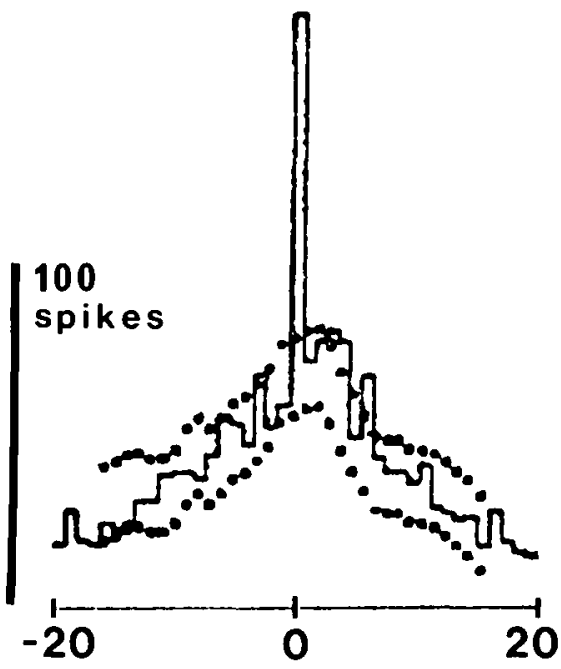

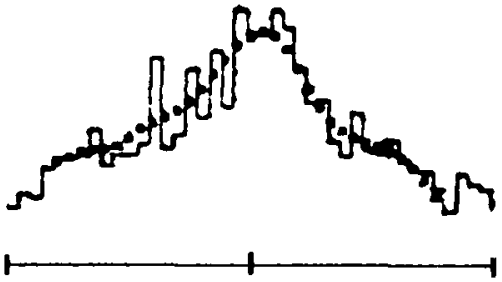

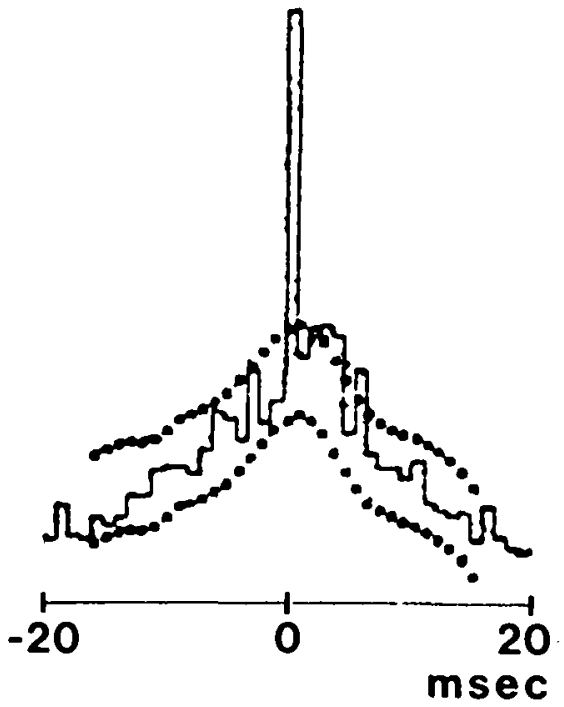

Figure 3-Peristimulus cross-interval histogram significance test. The central portion of the shift-control histogram is fitted by a moving average routine iterated 2 (A) or 5 (B) times. A 'standard deviation' is calculated from the differences between bin values and the fitted average curve. Then a band comprising the fitted curve plus and minus 2 standard deviations is plotted on top of the original histogram. Bin width is $1 \mathrm{msec}$.

ensuring a wide band of simultaneously activated parallel fibers (Fig. 1). The test used for determining the presence of common input to P-cells recorded on separate electrodes was a statistical one, namely a significant correlation between the times of firing for each P-cell. In general, correlation occurring at zero delay is unequivocal evidence for common input (Gerstein and Perkel, 1972). Since P-cells fire randomly in the absence of specific input (Sabah and Murphy, 1971) and do not excite one another, positive correlation of P-cell firing patterns even at small delays is indicative of common input.

Correlation of the stretch responses of P-cells recorded on each electrode was determined by constructing cross-interval histograms from the peri-stimulus portion of selected P-cell spike trains. Since the expected time relation was short compared to the mean interspike interval, the cross-interval histogram was judged to be an adequate test (Perkel et al., 1967). Indeed, the computation of cross-correlograms involving higher than first-order intervals added no information although it required more computer time. The spontaneous activity of mammalian P-cells is only correlated for pairs of neurons less than 100 $u$ apart (Bell and Grimm, 1969). To uncover any correlations over larger distances we thought it necessary to use evoked activity. For this reason 
cross-interval histograms were constructed from only the peri-stimulus portions of the 2 spike trains, starting $20 \mathrm{msec}$ before the initiation of muscle stretch and ending $128 \mathrm{msec}$ later. Simultaneous spike trains segmented about the stimulus are normally used to compute joint peri-stimulus time scatter diagrams (Gerstein and Perkel, 1972). We have found the histogram format, however, more amenable to an objective test of significance, particularly in this case where correlations were generally weak.

Our significance test was derived from that developed by Gerstein and Perkel (1972) for scatter diagrams. The cross-interval histogram was recompiled after "frame-shifting" one spike train with respect to the other by one stimulus cycle producing a "shift-control" histogram. A more thorough shuffling procedure was not considered necessary because there were no consistent trends in any of the spike trains used (ibid.). The latter condition was carefully checked by analysis of raster displays as reported elsewhere (Murphy et al., 1974). The central 33 bins of the shift-control histogram were then 'smoothed' using an iterative moving average routine (Blake, 1974). The smoothed curve was plotted as a series of dots over the histogram (Fig. 3). A single "standard deviation' was then calculated from the differences between original bin values and the fitted curve or 'mean'. (The decline in variance in some cases of the most peripheral bins was found to introduce only slight errors). Finally a band was plotted as 2 rows of dots on the original histogram, representing the fitted curve plus and minus 2 'standard deviations' (Fig. 3). This band contained approximately $95 \%$ of the cross-intervals where the spike trains were independent of each other, except for a mutual variable dependence on the muscle stimulus. Only bins with values which lay well outside the superimposed band were considered to demonstrate a significant temporal correlation between responses of the 2 cells. As shown in figure 3 , an increase in the number of iterations of the moving weighted average routine, from 2 (Fig. 3A) to 5 (Fig. 3B), produced a smoother fit. Generally, however, only 2 iterations were performed to prevent levelling of the central peak.

\section{Histology}

Animals were sacrificed with an overdose of barbiturate at the end of an experiment. Electrodes were cut and left in their last track, the cerebellum quickly removed and fixed in formalin for 2 days. Then 50 $\mu$ sections were sliced in the plane of the electrode tracks. All sections containing tracks where the electrode tip had been left in situ during fixation were easily found, mounted and stained with cresyl violet. The other electrode tracks were interpolated from the experimental protocol, making allowance for tissue shrinkage (measured to be about 15\%) Normally all the electrode tracks were made in the same plane (that of the sectioning), which greatly aided their reconstruction.

\section{RESULTS}

Shape of cortical zones responsive to muscle stretch:

We have previously reported that P-cells within a sagittally-oriented strip (about $1 \mathrm{~mm}$ wide and up to 10 $\mathrm{mm}$ long), located in the center of hemispheral lobule $V$ (pars intermedia), respond to moderate stretch of single ipsilateral forelimb muscles (Murphy et al., 1973). In addition to this major response zone, in recent experiments we have found evidence of two other narrow strips in lobule $\mathrm{V}$ responsive to the same elemental stimulus. One is parallel to

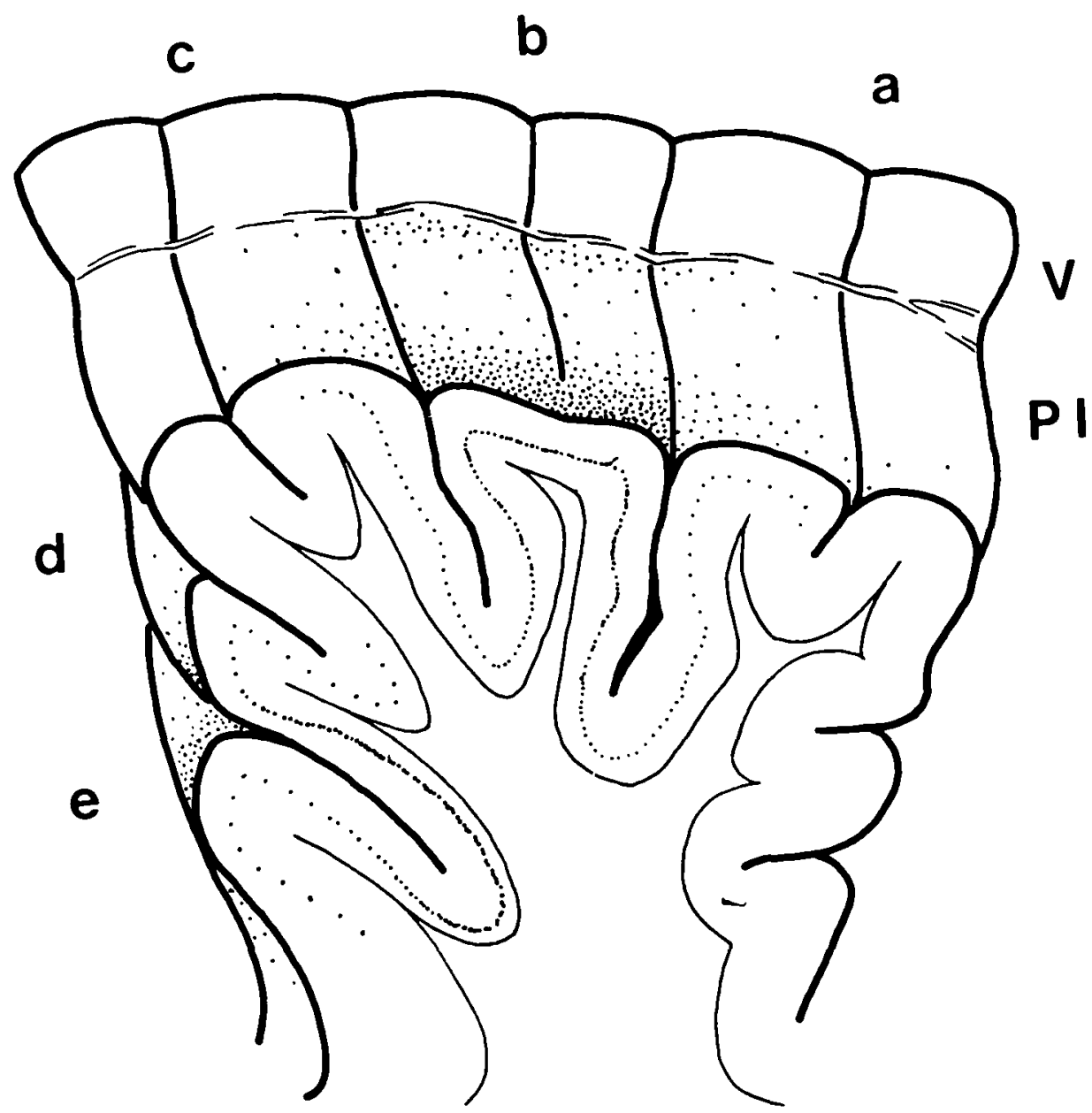

Figure 4-Lateral view of lobule V sectioned sagittally through the middle of pars intermedia (PI). Regions of high probability of P-cell responses to wrist muscle stretch are marked by accumulations of dots. $\mathrm{V}$, vermis. 
the zone just mentioned, at the medial edge of pars intermedia (Fig. 4). The other is further caudal in the depths of the fissura prime (Fig. 4), an area which responds to muscle nerve stimulation (Ekerot and Larson, 1972). Yet another responsive strip was found in the paramedian lobule, VIlla. In each case, however, the zone extends much farther in the sagittal plane than in the direction of the folial axes or parallel fibers. The elongation in the sagittal plane was to be expected from the known pattern of termination of the cuneocerebellar tract (Oscarsson, 1973; Voogd, 1969). But the present results (Figs. 4, 5) show that stretch of

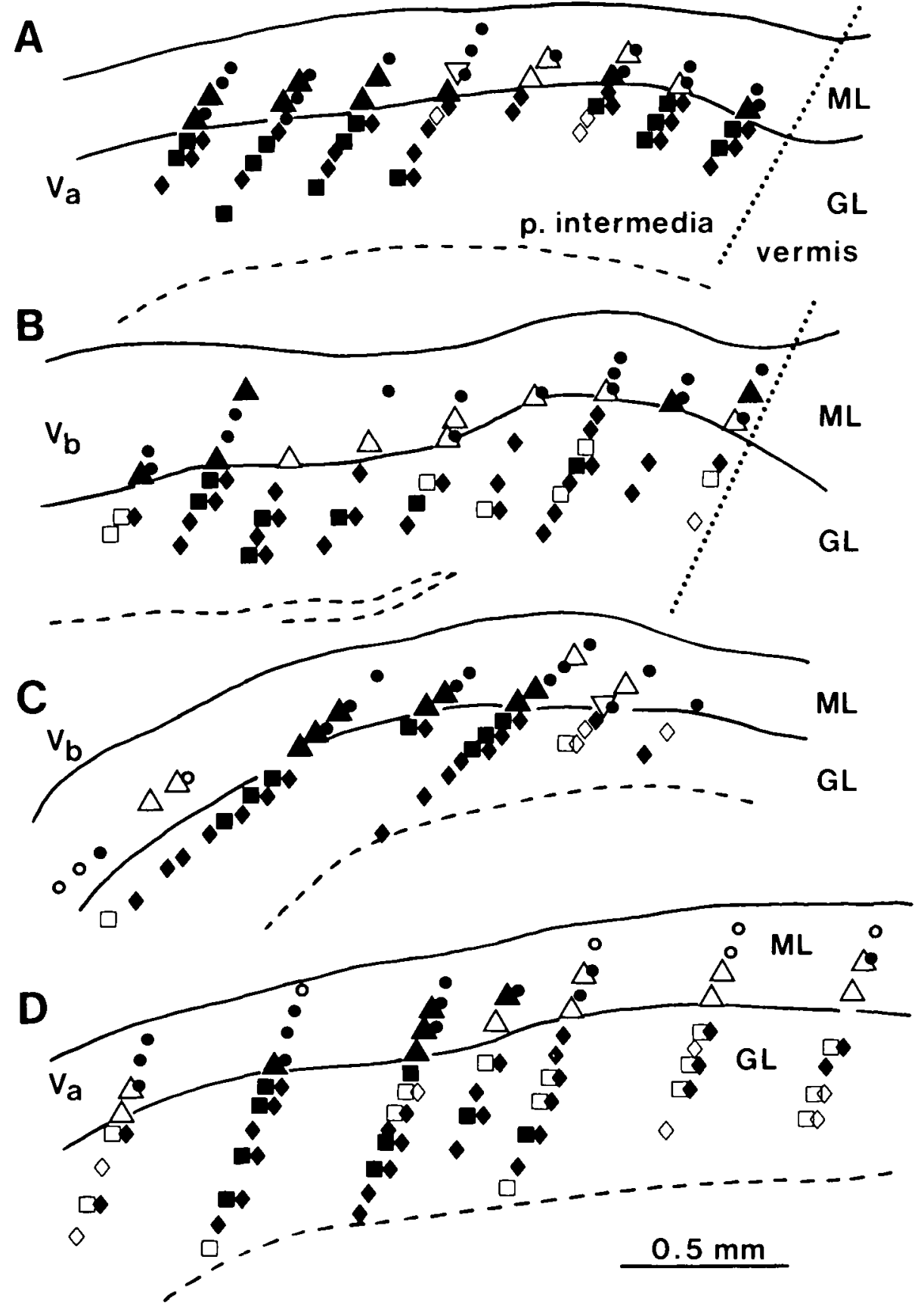

Figure 5-The distribution of unit responses in the long axis of various folia (pars intermedia). Solid symbols indicate an excitatory response and open symbols a lack of response: circle, molecular layer interneuron; triangle, P-cell; square, Golgi cell; diamond, granule cell. Inverted open triangles indicate an inhibitory P-cell response. ML, molecular layer; GL, granular layer. single muscles does not activate P-cells along the full length of parallel fiber "beams" which should be at least $2 \mathrm{~mm}$ long (Fox and Barnard, 1957; Palkovits et al., 1971). This basic observation may be restated as a conclusion: naturally activated parallel fiber beams do not necessarily fire P-cells along their entire length. Similarly, from the data reported by Eccles and coworkers (1972), P-cells responsive to toe pad taps appear to lie within very narrow parasagittal strips.

\section{Profile of the response zone}

By making multiple parallel electrode tracks across muscle stretch response zones, it was possible to determine, for each cortical layer, how far responsive cells extended in the direction of parallel fiber spread. Typical results are presented in Fig. 5. It is clear that of all the responsive neurons, P-cells were the most restricted in terms of spatial distribution. Responsive granule cells on the other hand, are the most widespread. It was not uncommon to record scattered granule cell responses from one side of pars intermedia to the other. The prompt curtailment of P-cell evoked activity in the direction of parallel fiber spread could be due both to the decreasing density of activated parallel fibers and to the continued responsiveness of molecular layer interneurons towards the edge of a response zone (Fig. 5). The inhibitory influence of the latter on P-cells would effectively cancel any excitatory input from the parallel fibers, or on occasion produce a net inhibition of P-cells at the fringe of a responsive area (Fig. 5, 6). The activated interneuron (probably a basket cell) and simultaneously inhibited $P$-cell shown in figure 6 were recorded together on the same electrode at the edge of a region in which P-cells were excited by muscle stretch. Since both molecular layer interneurons and P-cells derive their excitatory input from parallel fibers, it follows from figure 5 that molecular layer interneurons can be activated by a lower general density of active parallel fibers than P-cells.

The spatial character of the cortical zones responsive to muscle 


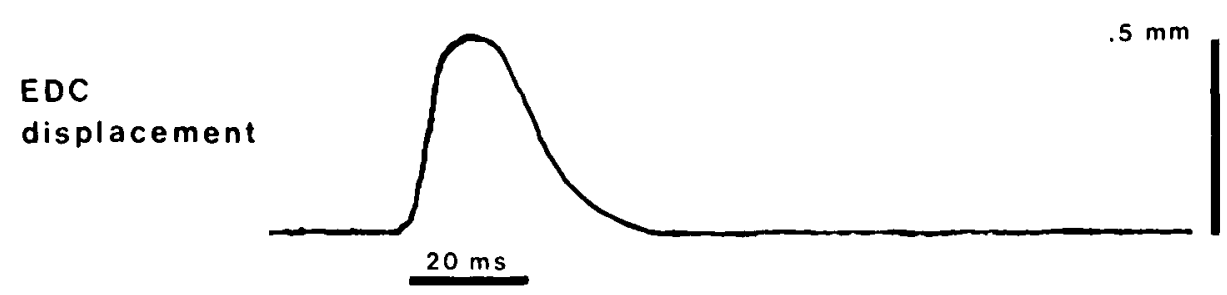

Purkinje

cell
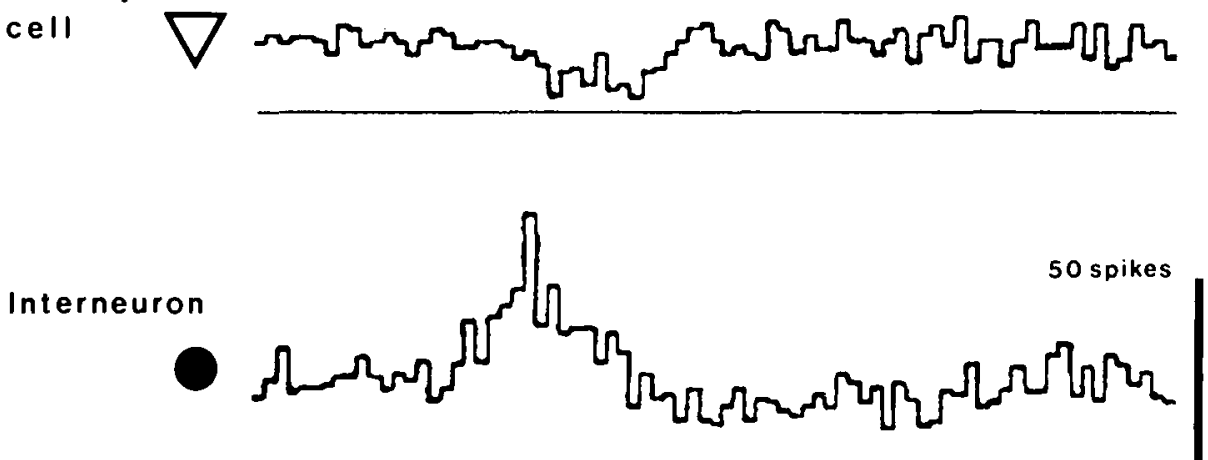

Figure 6-Simultaneously collected PSTHs from a P-cell and molecular layer interneuron recorded on the same electrode at the edge of a zone of excitatory P-cell responses to muscle stretch. Bin width is $2 \mathrm{msec}$; number of repetitions is 128 .

stretch conform best therefore to the "integrator" model (Fig. 1). The "delay line" configuration is prevented apparently by insufficient density of activated parallel fibers and by the action of inhibitory interneurons. Also, the dimensions of the distribution of excited cells are incompatible with a parallel fiber length much more than $2 \mathrm{~mm}$ (Brand et al., 1974; Houk and Walsh, 1971).

\section{Timing of P-cell responses}

lt was previously demonstrated that functional antagonists produce similar actions on the same P-cell and activate similar cortical zones (Murphy et al., 1973), but when 2 antagonists (EDC and PL) are pulled simultaneously, the width of the major zone of responsive P-cells (Fig. 4) can be increased from $1 \mathrm{~mm}$ to about $2 \mathrm{~mm}$ (making it continuous with the more medial zone), thus giving more space in which to test for any constant delays between P-cell responses as predicted by Braitenberg's model.

Only the exposed dorsal folia of the intermediate culmen, a region which is accurately approachable, was examined. Cross-interval histograms were compiled from the peri-stimulus portions of the spike trains of pairs of simultaneously re- corded P-cells (see Methods). Two P-cells recorded on the same electrode anywhere in the response zone

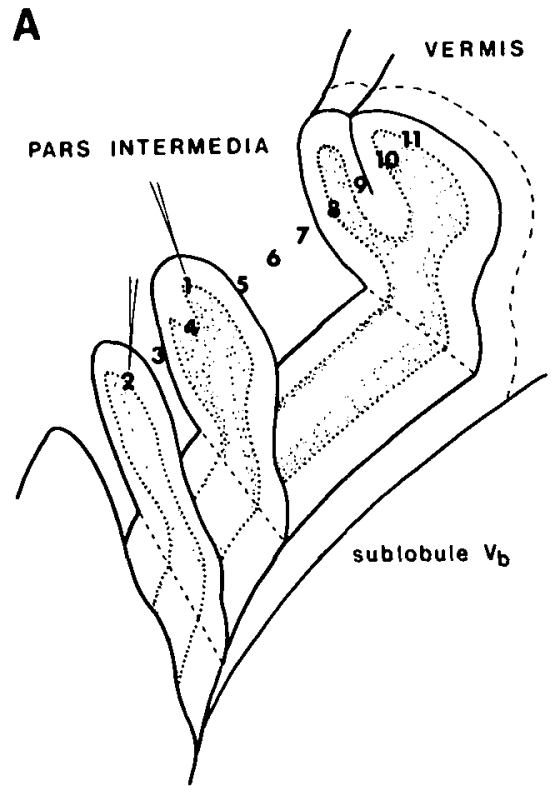

B
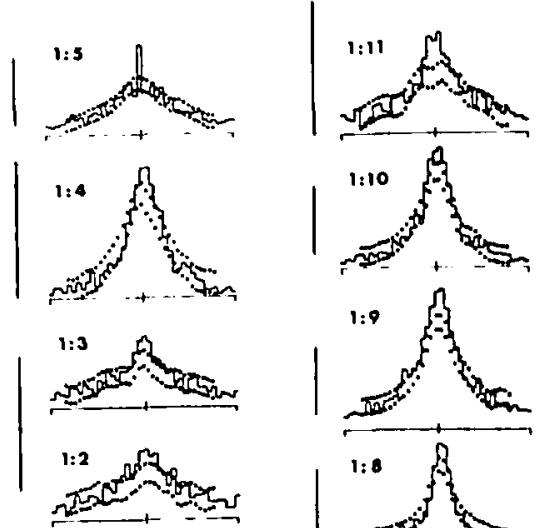

showed a sharp correlation at zero delay. The correlation was repeated with a $0.5 \mathrm{msec}$ bin width (Fig. 8) and again the peak was centered at zero delay. More distant pairs either showed no significant correlation (Fig. 7, 1:6) or a low broad peak always centered on zero delay (Fig. 7 , 1:11).

The average conduction velocity

Figure 7-Peristimulus cross-interval histograms for pairs of P-cells within a muscle stretch response zone. The numbers in A mark the electrode positions at which P-cells were recorded. One electrode remained stationary at position 1 . The other was moved in the folial axis from position 2 to 11 in $0.2 \mathrm{~mm}$ increments except for a $0.4 \mathrm{~mm}$ jump between positions 4 and 5 . Position 5 is approximately $0.2 \mathrm{~mm}$ anterior and $0.1 \mathrm{~mm}$ medial to position 1 . The histograms in $B$ show the distribution of cross-intervals between spikes of a P-cell recorded at position 1 and the spikes of $P$-cells recorded at positions 2 to 11 inclusive. Bin width of the histograms is $1 \mathrm{msec}$; stimulus was repeated 128 times. 


\section{A}

\section{shift control}

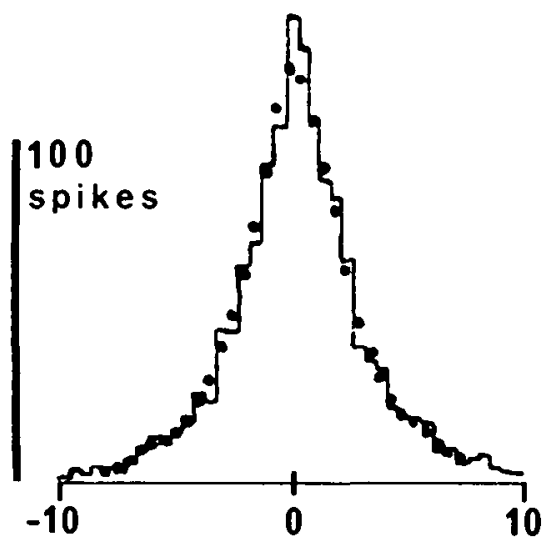

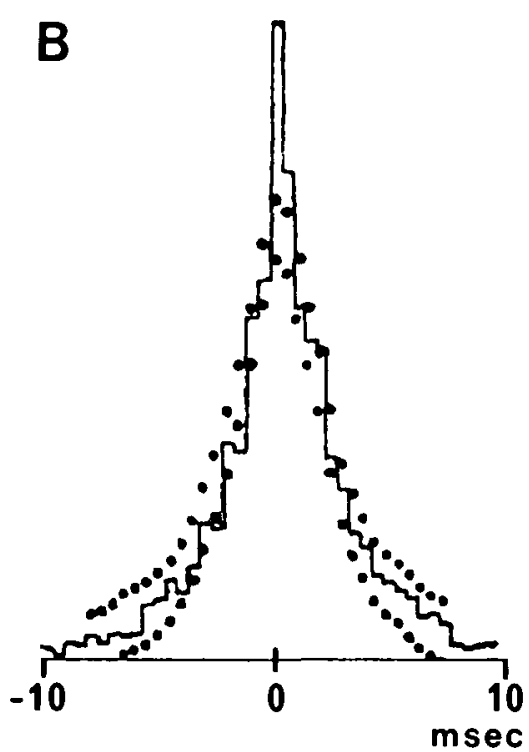

Figıre 8-Peristimulus cross-interval histogram (B) and shift-control histogram (A) for P-cells recorded at positions 1 and 5 in figure 7 . Bin width is $0.5 \mathrm{msec}$; stimulus was repeated 128 times.

of cat parallel fibers is at least $0.3 \mathrm{~m} / \mathrm{sec}$. (Eccles et al., 1967; Gardner-Medwin, 1972), allowing a total conduction time of approximately $3 \mathrm{msec}$ for impulses to travel from position 1 in Fig. 7 to a point 1 $\mathrm{mm}$ medial or lateral. But when distances of $1 \mathrm{~mm}$ or greater (up to 1.3 $\mathrm{mm}$ ) separated a pair of recorded P-cells, a consistent delay of $3 \mathrm{msec}$ or more between responses of the 2 cells was not observed in the crossinterval histograms. Normally no more than $1 \mathrm{msec}$ separated responses of distant P-cells (Fig. 7). This finding leads one to conclude that the cerebellar cortex effects a relatively simultaneous activation of a specific zone of $P$-cells, rather than a sequential activation along beams of parallel fibers.

\section{Minimum latency of \\ $P$-cell responses}

Although the average $\mathrm{P}$-cell response time which is monitored in the cross-interval histogram, is virtually identical across an entire response zone, in all experiments it was noticed that the minimum response latency increased as one moved from the center towards the medial and lateral edges of the zone (Fig. 9, 10, 11A). Presumably, the minimal latency is an indication of the earliest synaptic input to a neuron, which only rarely is sufficient to excite the neuron. (Minimum response latency was measured as the time from the initial rise in muscle tension to the first significant bin in the PSTH peak). From the viewpoint of this study it was important to determine whether or not the increase in minimal latency with increasing distance from the response focus could be accounted for by the conduction velocity of parallel fibers.

To approach this question adequately, it was also necessary to measure the distribution of minimal latencies in the granular layer in order to identify the configuration of parallel fiber activity responsible for the earliest $P$-cell responses. The results of one such experiment are shown in figure 10. Both granule and P-cells follow the same trend: shortest latencies in the center of the response zone and longer towards the edges. The P-cell data was fitted with a parabolic regression curve. The significant feature however, is the spatial extent of the earliest firing granule cells. They are limited to the region directly underlying the total P-cell response zone (Fig. 10), and are activated more or less synchronously.

We can, therefore, picture the earliest input to a zone of responsive $P$-cells as represented in the discrete, lumped model of Fig. 11B.
The earliest parallel fiber input to the $\mathrm{P}$-cell population arises only from granule cells directly beneath that population. Because P-cells in the center of the response zone receive parallel fiber inputs at a faster rate than those at the periphery, it follows that the minimal response latency will increase from the center to the periphery as observed (Fig. $10,11 \mathrm{~A})$. (The molecular layer inhibitory interneurons are excited by the same parallel fibers which excite the P-cells and therefore do not significantly affect the pattern of earliest excitatory input to P-cells).

Latency differences between neighboring $\mathrm{P}$-cells can be estimated in a piece-wise linear fashion from the model of Fig. 11B using only conduction velocity considerations and the assumption that the probability of one cell firing before its neighbour is linearly related to the proportion of active parallel fibers reaching one cell before the other. The latter proportion has been calculated for the model in figure 11B and labelled the "delay line quotient". It is determined by dividing the total number of fibers conducting in one direction into the excess number (i.e. unbalanced by parallel fibers travelling the opposite way) conducting in the same direction through the dendritic trees of a pair of neighboring P-cells (Fig. 11B). The firing delay between the two $\mathrm{P}$-cells is then given by the following expression: (distance/conduction velocity) $X$ (delay line quotient). Where all the active parallel fibers reach one $\mathrm{P}$-cell before the other the delay line quotient is 1.0 (5/5 in Figure 11B) and latency differences are directly proportional to the reciprocal of parallel fiber conduction velocity. Where equal numbers of active parallel fibers approach from either side the delay line quotient is 0.0 and both P-cells of a neighboring pair fire at the same time. (It should be noted that the actual average length of parallel fibers, whatever it may be, does not alter the distribution of delay line quotients in Fig. 11B).

In figure $11 \mathrm{~A}$ it is clear that the latency curve predicted from purely delay line effects (broken curve) is 
LE JOURNAL CANADIEN LES SCIENCES NEUROLOGIQUES

DISPLACEMENT

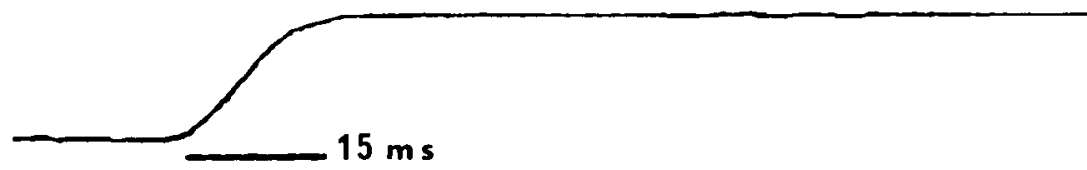

PATHS

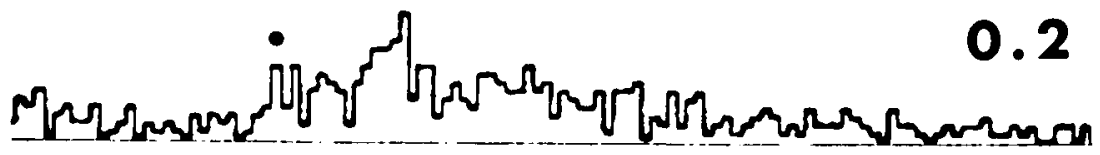

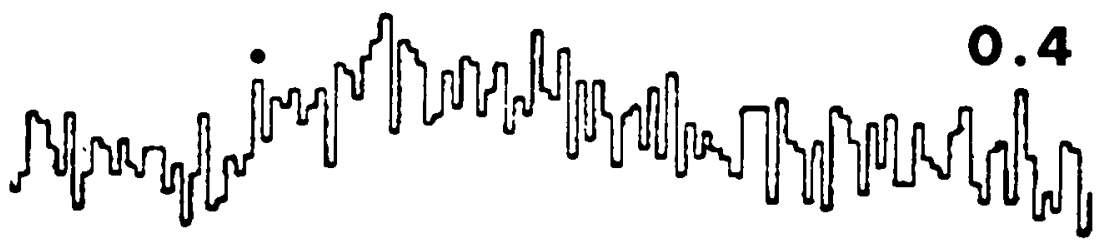
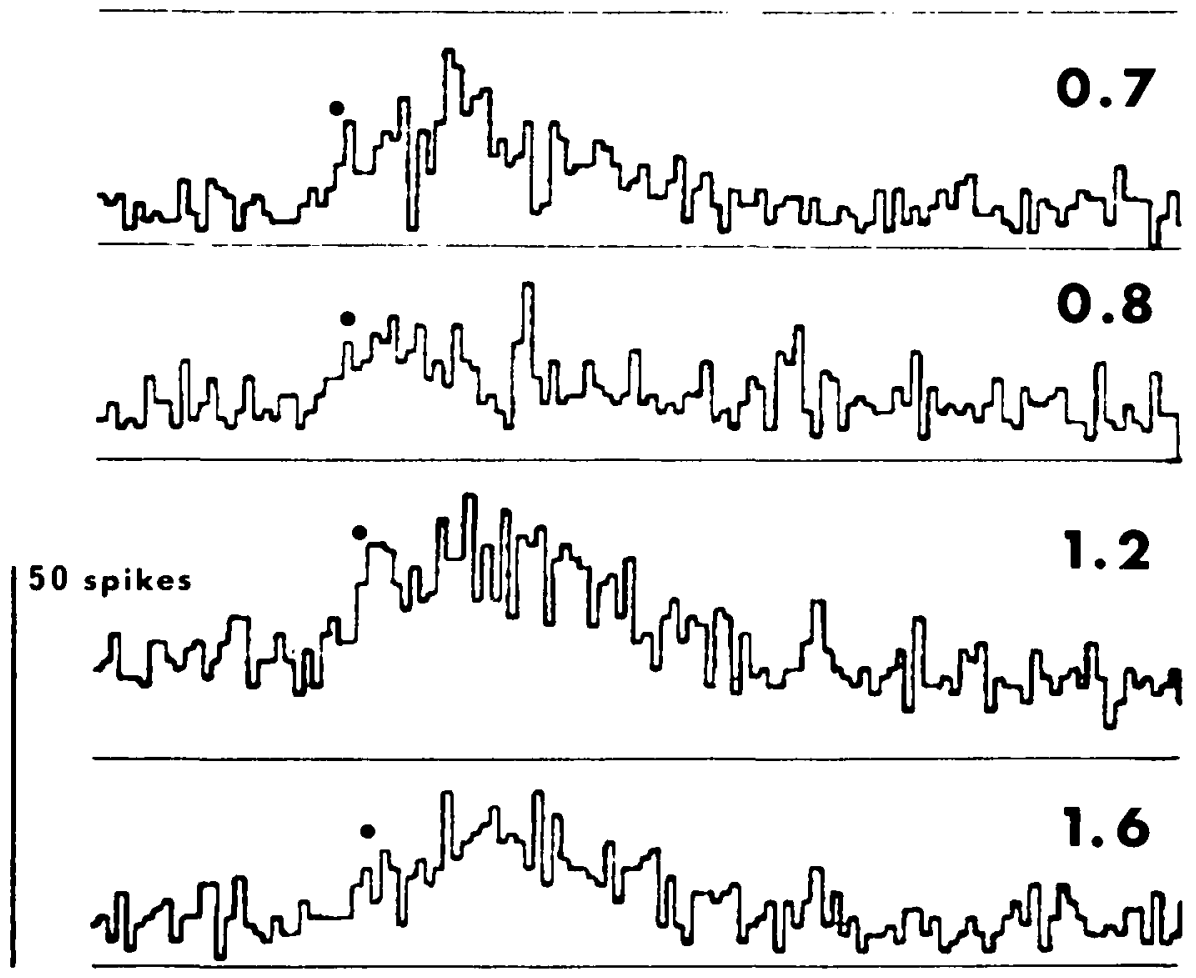

Figure 9-PSTHs of P-cells at different positions within the 2-muscle stretch response zone, from the lateral $(0.0)$ to the medial $(1.6 \mathrm{~mm})$ side of the zone. Dots mark the first significant bins of response peaks. Bin width is $1 \mathrm{msec}$; number of repetitions is 128. not an adequate description of the experimental data. A delay line explavation of the data in figures 10 and $11 \mathrm{~A}$ would require average parallel fiber conduction velocities of $1 / 3$ to $1 / 2$ their actual values. One must conclue, therefore, that a volley from the initially excited population of granule cells is at best sufficient to excite the most central of the directly overlying P-cells, while the rest must await later inputs for cactivation. Furthermore, the diversity of later inputs (from more slowly conducting parallel fibers, from long parallel fibers originating in distant response zones, and from lateractivated granule cells both within the region of initial activity and outside it) would obliterate any delay line tendencies subliminally present in the early response pattern.

Thus, all of the evidence pressented here indicates that the density of parallel fibers excited from a restricted granular locus is too small to present an effective stimulus to P-cells. Where the "delay line quotent". is 1.0 , apparently no P-cells are excited. The successful activeton of P-cells requires the approach of excited parallel fibers from both directions. The spatial picture is further complicated by a lack of synchron in the initiation of impulses within the granule cell population (Fig. 10). It appears that the observeable differences in minimum respouse latency between P-cells (Fig. $11 \mathrm{~A}$ ) are determined as much by this factor as by parallel fiber conduction times.

DISCUSSION

Sub-mammalian cerebella

There is little doubt that a row of P-cells in dogfish cerebellum would fire in sequence as a volley of action potentials travelled along the unidirectional bundle of parallel fibers linking them (Nicholson et al., 1969). Similarly it is known that pairs of P-cells in frog cerebellum may fire in sequence with a delay appropriate to the conduction veloceit of the parallel fibers. Anuran parallel fibers are proportionately longer than those of mammals, stretching from one side of the cere-

MacKay and Murphy

MAY $1976-93$

https://doi.org/10.1017/S031716710002583X Published online by Cambridge University Press 


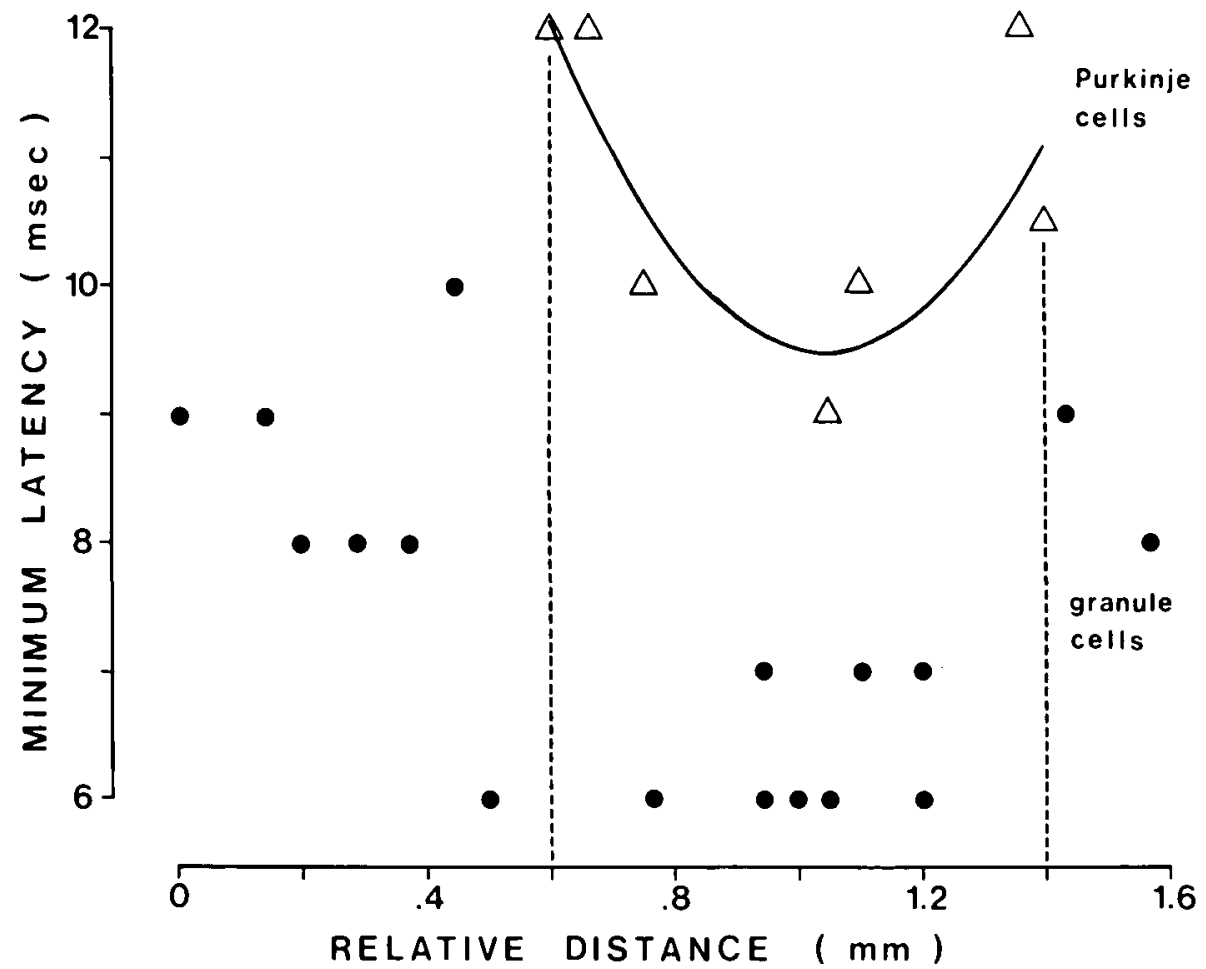

Figure 10-Spatial distribution of minimal response latencies for P-cells (triangles) and granule cells (circles) across a response zone from the lateral $(0.0)$ to the medial (1.6 $\mathrm{mm}$ ) side. The P-cell data has been fitted with a parabolic regression curve.

bellum to the other (Kemali and Braitenberg, 1969). Consequently in anurans a higher fraction of the parallel fibers linking a pair of P-cells 250 or 500 uapart originate from outside the granular region lying between the 2 cells (Freeman, 1969). The delay-line configuration, therefore, has a relatively greater potency in anuran than it does in mammalian cerebella. Moreover, a vestibular stimulus, such as that used by Freeman and Nicholson (1970) mainly activates the lateral edge (auricle) of the cerebellum (Precht and Llinas, 1969), whence the parallel fibers spread uni-directionally towards the midline, tending to activate $\mathrm{P}$-cells in sequence along their path.

Because of the lack of delay-line properties in mammalian cerebellar cortex as demonstrated in this study, the question must be raised to what extent the delay line character of parallel fibers in elasmobranchs and amphibians is an epiphenomenon. The thrust of evolution has increased the parallel fiber: P-cell ratio (Lange, 1975; Llinás and Hillman, 1969) and decreased the length of parallel fibers relative to the width of the cerebellum (Nicholson et al., 1969; Palkovits et al., 1971) in phase with the increasing complexity of cerebellar compartmentalization. These developments would tend to compromise delay-line qualities, while maintaining and in fact enhancing the machinery for mixing together inputs to neighbouring sagittal regions. Since it is unlikely that the overall strategy of cerebellar operation has been radically changed in the course of vertebrate evolution, it is plausible to hypothesize that parallel fibers have an integrative function throughout the phylogenetic spectrum. Thus, while not all cerebella can work as delay lines, they are all capable of integrating diverse mossy fiber inputs.

\section{Role of inhibitory interneurons}

The loss of delay-line characteristics in mammalian as compared to elasmobranch and anuran cerebella is paralleled by the increasing specialization and development of inhibitory interneurons in the former (Llinás and Hillman, 1969). One may, therefore, infer that the in- creasing importance of inhibitory interneurons in mammalian cerebellar cortex is partly responsible for the suppression of delay-line properties. This conjecture is supported by the findings of our study. Firstly, the molecular layer interneurons are excited by lower densities of parallel fiber activity than P-cells (Fig. 5) and therefore act to prevent P-cell responses at the fringes of an active region where the delay line quotient is approaching 1.0. Because they synapse directly on P-cell somata (Eccles et al., 1967), basket cells are probably instrumental in defining the borders of a response zone. Secondly, the central portion of the granular response zone is a site of pronounced Golgi cell activity (Fig. 5 ), which acts to reduce the general level of granule cell excitation in this region. Therefore a concentrated focus of granule cell activity, as required by the delay-line model (Fig. 1 ), is not allowed to develop. Golgi cells ensure a relatively even spread of granule cell activity over a zone supplied by a specific mossy fiber set.

Besides limiting the width of a $P$-cell response zone in the direction of parallel fiber spread, molecular layer interneurons may help to synchronize the firing of P-cells across a response zone. It was found experimentally that the earliest excitatory input to P-cells was strongest in the center of the response zone (Fig. 11 ), and yet most P-cell responses occurred simultaneously. Since molecular layer interneurons respond to parallel fiber volleys which are too weak to excite P-cells (Fig. 5), it follows that although the earliest parallel fiber input usually fails to excite the central P-cells, it probably does excite the central inhibitory interneurons. Indeed, on re-examining our PSTH data we observed that the interneuronal responses were skewed so that most of the spikes occurred before the majority of P-cell spikes (cf. Fig.2) although the minimal latencies for both were similar. As a result, central P-cell discharges tend to be delayed until a time when a much wider population of granule cells is activated, and most P-cells in the re- 


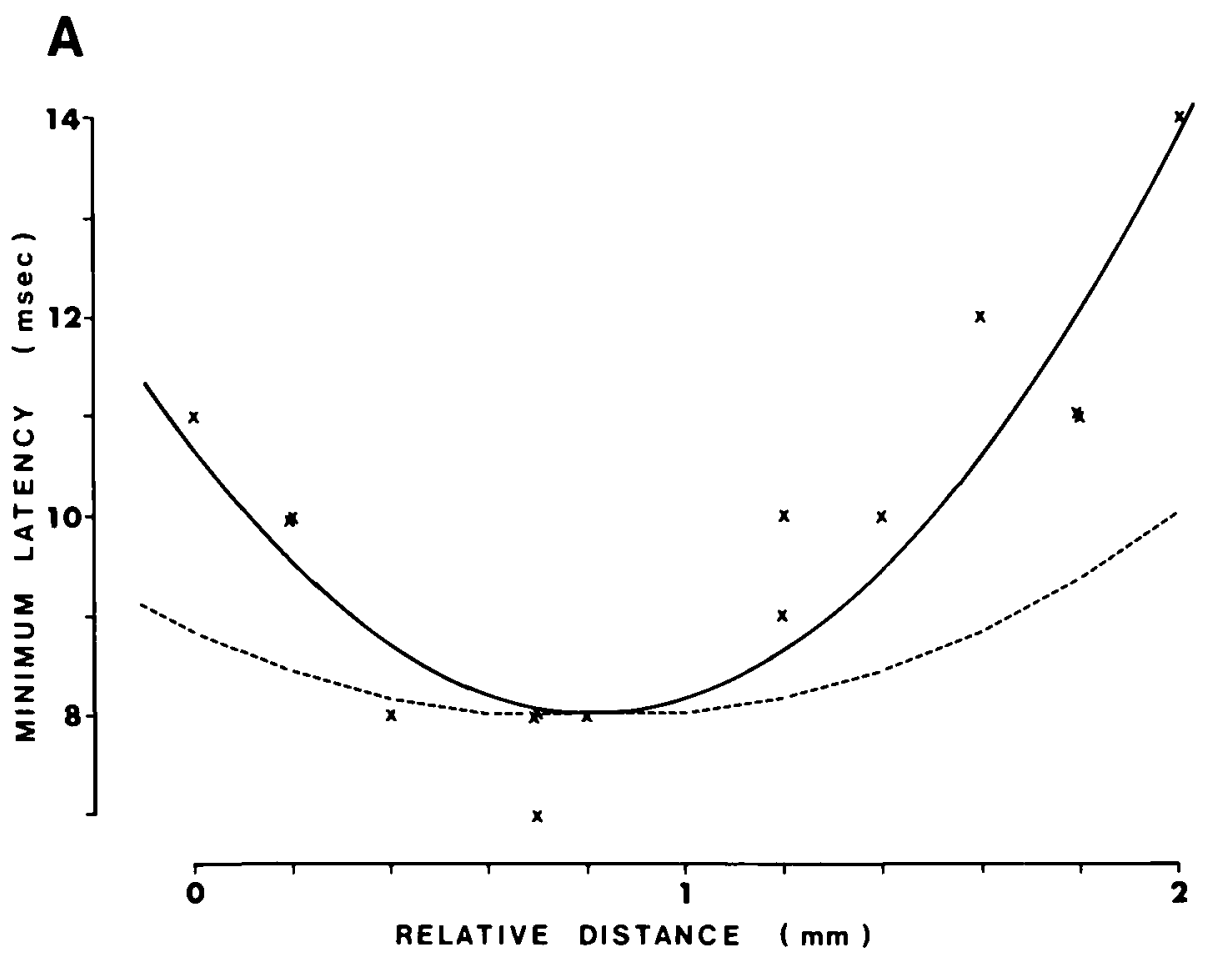

B

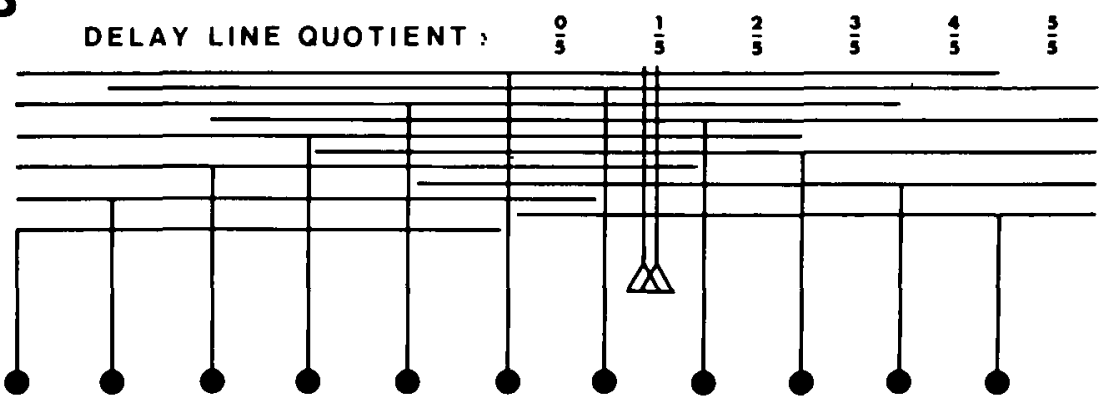

Figure /1-Spatial distribution of minimal response latencies for P-cells across a response zone from the lateral $(0.0)$ to the medial $(2.0 \mathrm{~mm})$ side. In $A$, the observed distribution of minimal latencies has been fitted with a parabolic regression curve for comparison with the latency function predicted from parallel fiber conduction velocity and the expected proportions of parallel fibers conducting orthodromically in one direction (delay line quotient). The latter is indicated by a broken line. A discrete lumped model of the parallel fiber configuration responsible for the earliest synaptic input to a P-cell response zone is presented in $\mathrm{B}$. The delay line quotient is given for each lumped segment, and a pair of neighboring P-cells within one segment is presented.

sponse zone are receiving approximately the same net excitation.

The stellate cells, because they inhibit branches of the P-cell dendritic tree, are particularly suited to 'levelling' the density of excitatory synaptic input across the response zone. In the central area, where the degree of parallel fiber convergence is maximal, stellate cell activity would presumably also be maximal does not inhibit a P-cell in a zone of more diffuse parallel fiber activity.

\section{Significance of an integrator model}

Exploiting his discovery of variations in fiber caliber within the folial white matter, Voogd (1969) has subdivided the cerebellar cortex into 7 longitudinal zones. His sagittal band termination pattern for the olivocerebellar projection has been supported anatomically (Courville et al., 1974) and physiologically (Armstrong et al., 1973; Oscarsson, 1973). Moreover, Ekerot and Larson (1973) have found a correspondence between the longitudinal terminal zones of mossy and climbing fiber pathways travelling in the dorsal funiculus of the spinal cord. It is possible, therefore, that parasagittal strips of P-cells constitute the functional output units of cerebellar cortex. This postulate, combined with the concept of P-cell integration suggests that cerebellar cortex impartially summates subsets of a wide variety of information of potential use in motor control upon specific output strips of P-cells.

Mossy fibers carrying information from a specific sensory modality or CNS locus ramify greatly within certain cortical regions to thoroughly mingle with other mossy fibers to the same regions. They branch most profusely in the sagittal plane (Eccles et al., 1967), but also cover a relatively wide area in the frontal plane (Szentágothai, 1968). Moreover, collateral branches are sent to lobules often separated by a great distance (Bloedel, 1975). It seems likely that a given mossy fiber would mingle with a different population of inputs within each region to which it projected. For each region the parallel fiber system then focusses mossy fiber input onto a P-cell output strip situated over the center of the population of active inputs to that region.

If, as we claim, the cerebellar cortex is primarily concerned with mixing inputs together, it may seem strange that several of the channels to the cortex, such as the cuneocerebellar and dorsal spinocerebellar tracts, maintain a 
careful separation of sensory modalities (Cooke et al., 1971; Oscarsson, 1973; Rosén and Sjölund, 1973). This is, however, essential for two reasons. Firstly, once modalities have converged onto a single mossy fiber they cannot be separated again to be individually mixed with yet another input. Secondly, an afferent system in which information is separated out on different lines allows for selective inhibition of one line of information when that information is temporarily detrimental to motor control, without compromising another line which may still be required. Indeed, there is evidence that both the cuneocerebellar (Cooke et al., 1971) and dorsal spinocerebellar tracts (Bloedel, 1975) can be inhibited either from the periphery or by pathways descending from supraspinal levels.

The integrating power of the parallel fiber-P-cell system is also enhanced by the likelihood of dendritic spike generating zones in $\mathrm{P}$-cells (Llinás and Nicholson, 1971; Sabah and Murphy, 1971), which would remove much of the bias in favor of synapses near the soma. As pointed out by Llinás and Nicholson (1971), spike generating zones within the dendritic tree (probably at branch points) provide a "booster" mechanism for parallel fiber inputs to the upper parts of the P-cell arborization. Thus, all of the parallel fiber synapses would have a reasonably equal influence on the final P-cell output.

In conclusion, the weight of evidence, both anatomical and physiological, supports the concept of an integrative parallel fiber function, as opposed to a timing function. Consequently each excited patch of P-cells should be viewed as the summed output of a specific subset of cerebellar afferents, presumably used for accurate control of specific movements.

\section{ACKNOWLEDGEMENTS}

This research was supported by the Medical Research Council of Canada. Grants from the Atkinson Foundation for equipment used in this study are also gratefully acknowledged.

\section{REFERENCES}

ALLEN, G. I., AZZENA, G. B. and OHNO, T. (1974). Somatotopically organized inputs from fore- and hindlimb areas of sensorimotor cortex to cerebellar Purkyne cells. Experimental Brain Research, 20, 255-272.

ARMSTRONG, D. M., HARVEY, R. J. and SCHILD, R. F. (1973). The spatial organization of climbing fibre branching in the cat cerebellum. Experimental Brain Research, $18,40-58$.

BELL, C. C. and GRIMM, R. J. (1969). Discharge properties of Purkinje cells recorded on single and double microelectrodes. Journal of Neurophysiology, 32, 1044-1055.

BLAKE, R. C. (1974). Weighted averaging simplifies curve fitting. Electronics, 47 (5), 136-138.

BLOEDEL, J. R. (1975). Cerebellar afferent systems: a review. Progress in Neurobiology, 2, 1-68.

BRAITENBERG, V. (1961). Functional interpretation of cerebellar histology. Nature, 190, 539-540.

BRAND, S., DAHL, A. and MUGNAINI, E. (1974). Length of parallel fibers in the cat cerebellar cortex. Anatomical Record, 178, 315.

COOKE, J. D., LARSON, B., OSCARSSON, O. and SJÖLUND, B. (1971). Organization of afferent connections to cuneocerebellar tract. Experimental Brain Research, 13, 359-377.

COURVILLE, J., FARACO-CANTIN, F. and DIAKIW, N. (1974). A functionally important feature of the distribution of the olivo-cerebellar climbing fibers. Canadian Journal of Physiology and Pharmacology, 52, 1212-1217.

ECCLES, J. C., FABER, D., MURPHY, J. and SABAH, N. and TÁBOŘIKOVÁ, $\mathrm{H}$. (1971a). Afferent volleys in limb nerves influencing impulse discharges in cerebellar cortex. I. In mossy fibers and granule cells. Experimental Brain Research, 13, 15-35.

ECCLES, J. C., FABER, D., MURPHY, J., SABAH, N. and TABORIKOVA, $H$. (1971b). Afferent volleys in limb nerves influencing impulse discharges in cerebellar cortex. II. In Purkyne cells. Experimental Brain Research, 13, 36-53.

ECCLES, J. C., FABER, D., MURPHY, J., SABAH, N. and TÁBORIKOVA, H. (1971c). Investigations on integration of mossy fiber inputs to Purkyne cells in the anterior lobe. Experimental Brain Research, 13, 54-77.

ECCLES, J. C., ITO, M. and SZENTÁGOTHAI, J. (1967). "The Cerebellum as a Neuronal Machine." New York, Springer.

ECCLES, J. C., SABAH, N., SCHMIDT, R. and TÁBORIKOVÁ, H. (1972). Integration by Purkyne cells of mossy and climbing fiber inputs from cutaneous mechanoreceptors. Experimental Brain Research, 15, 498-520.

EKEROT, C. F, and LARSON, B. (1972). Differential termination of the exteroceptive and proprioceptive components of the cuneocerebellar tract. Brain Research, 36, 420-424.

EKEROT, C. F. and LARSON, B. (1973). Correlation between sagittal projection zones of climbing and mossy fibre paths in cerebellar anterior lobe. Brain Research, 64, 446-450.

FOX, C. A. and BARNARD, J. W. (1957). A quantitative study of the Purkinje cell dendritic branchlets and their relationship to afferent fibres. Journal of Anatomy, 91, 299-313.

FREEMAN, J. A. (1969). The cerebellum as a timing device: an experimental study in the frog. In: Neurobiology of Cerebellar Evolution and Development, edited by $R$. Llinas, American Medical Association: Chicago, pp. 397-420.

FREEMAN, J. A. (1970). Responses of cat cerebellar Purkinje cells to convergent inputs from cerebral cortex and peripheral sensory systems. Journal of Neurophysiology, 33, 697-712.

FREEMAN, J. A. and NICHOLSON, C. N. (1970). Space-time transformation in the frog cerebellum through an intrinsic tapped delay-line. Nature, 226, 640-642.

GARDNER-MEDWIN, A. R. (1972). An extreme supernormal period in cerebellar parallel fibres. Journal of Physiology, 222, 357-371.

GERSTEIN, G. L. and PERKEL, D. H. (1972). Mutual temporal relationships among neuronal spike trains. Statistical techniques for display and analysis. Biophysical Journal, 12, 453-473.

HOUK, J. C. and WALSH, J. V. (1971). The length and organization of parallel fibres. International Congress of Physiological Sciences, Proceedings, p. 263.

KEMALI, $M$, and BRAITENBERG, V. (1969). Atlas of the frog's brain. New York, Springer-Verlag.

KORNHUBER, H. H. (1971). Motor functions of cerebellum and basal ganglia: The cerebellocortical saccadic (ballistic) clock, the cerebellonuclear hold regulator, and the basal ganglia ramp (voluntary speed smooth movement) generator. Kybernetik, 8 , 157-162.

KWAN, H. C. and MURPHY, J. T. (1974). Extracellular current density analysis of responses in cerebellar cortex to mossy fiber activation. Journal of Neurophysiology, 37 , 947-953.

LANGE, W. (1975). Cell number and cell density in the cerebellar cortex of man and some other mammals. Cell Tissue Research, 157, 115-124.

LLINÁS, R. and HILLMAN, D. E. (1969). Physiological and morphological organization of the cerebellar circuits in various vertebrates. In: Neurobiology of Cerebellar Evolution and Development, edited by R. Llinás, American Medical Association: Chicago, pp. 43-73.

LLINÁS, R. and NICHOLSON, C. (1971). Electrophysiological properties of dendrites and somata in alligator Purkinje cells. Journal of Neurophysiology, 34 . 532-551. 
MacKAY, W. A. and MURPHY, J. T. (1973). Profile of a simple cerebellar cortical response zone. Canada Physiology, 4, p. 41.

MacKAY, W. A. and MURPHY, J. T. (1974). Responses of interpositus neurons to passive muscle stretch. Journal of Neurophysiology, 37, 1410-1423.

MacKAY, W. A. and MURPHY, J. T. (1975). A mechanism for cerebellar integration. Canadian Federation of Biological Societies, Proceedings, 18, p. 148.

MUGNAINI, E., ATLURI, R. L. and HOUK, J. C. (1974). Fine structure of granular layer in turtle cerebellum with emphasis on large glomeruli. Journal of Neurophysiology, 37, 1-29.

MURPHY, J. T., KWAN, H., MacKAY, W. A. and WONG, Y. C. (1974). Evaluation of neuronal spike trains in neurophysiological experiments. Physiology and Behavior, 13 , 313-315.

MURPHY, J. T., MackAY, W. A. and JOHNSON, F. (1973). Differences between cerebellar mossy and climbing fibre responses to natural stimulation of forelimb muscle proprioceptors. Brain Research, 55, 263-289.
NICHOLSON, C.. LLINÁS, R, and PRECHT, W. (1969). Neural elements of the cerebellum in elasmobranch fishes: structural and functional characteristics. In: Neurobiology of Cerebellar Evolution and Development, edited by $\mathrm{R}$. Llinás, American Medical Association: Chicago, pp. 215-243.

OSCARSSON, O. (1973). Functional organization of spinocerebellar paths. In: Handbook of Sensory Physiology, vol. II. Somatosensory System, edited by A. Iggo, Springer: New York, pp. 339-380.

PALKOVITS, M., MAGYAR, P. and SZENTÁGOTHAI, J. (1971). Quantitative histological analysis of the cerebellar cortex in the cat. III. Structural organization of the molecular layer. Brain Research, 34, 1-18.

PERKEL, D., GERSTEIN, G. and MOORE. G. (1967). Neuronal spike trains and stochastic point processes. II. Simultaneous spike trains. Biophysical Journal, 7. 419-440.

PRECHT, W. and LLINÁS, R. (1969). Functional organization of the vestibular afferents to the cerebellar cortex of frog and cat. Experimental Brain Research, 9, 30-52.
ROSÉN, I. and SJÖLUND, B. (1973). Organization of group I activated cells in the main and external cuneate nuclei of the cat: convergence patterns demonstrated by natural stimulation. Experimental Brain Research, 16, 238-246.

SABAH, N. H. and MURPHY, J. T. (1971). A superposition model of the spontaneous synaptic excitation of cerebellar Purkinje cells. Biophysical Journal, 11, 414-428.

SZENTÁGOTHAI, J. (1968). Structurofunctional considerations of the cerebellar neuron network. Institute of Electrical and Electronic Engineers, Proceedings, 56. 960-968.

WALSH, J. V., HOUK. J. C. and MUGNAINI, E. (1974). Identification of unitary potentials in turtle cerebellum and correlations with structures in granular layer. Journal of Neurophysiology, 37, 30-47.

VOOGD, J. (1969). The importance of fiber connections in the comparative anatomy of the mammalian cerebellum. In: Neurobiology of Cerebellar Evolution and Development, edited by R. Llinás, American Medical Association: Chicago, pp. 493-514. 